\title{
Fallopian Tube Teratoma
}

National Cancer Institute

\section{Source}

National Cancer Institute. Fallopian Tube Teratoma. NCI Thesaurus. Code C40131.

A teratoma that arises from the fallopian tube. It is a rare tumor, often found incidentally. 